\title{
SPONTANEOUS RESOLUTION OF A NONFUNCTIONING PITUITARY ADENOMA OVER ONE-MONTH PERIOD: A CASE REPORT
}

\author{
Luka Komić ${ }^{1}$, Ivan Kruljac ${ }^{2}$, Gorana Mirošević ${ }^{2}$, Petar Gaćina ${ }^{3,4}$, Hrvoje Ivan Pećina ${ }^{5}$, \\ Vatroslav Čerina $^{6}$, Domagoj Gajski ${ }^{4,6,7}$, Kristina Blaslov ${ }^{2}$, Krešimir Rotim ${ }^{6,7,8}$ and Milan Vrkljan ${ }^{2,9}$ \\ ${ }^{1}$ University of Split, School of Medicine, Split, Croatia; \\ ${ }^{2}$ Mladen Sekso Department of Endocrinology, Diabetes and Metabolic Diseases, \\ Sestre milosrdnice University Hospital Centre, Zagreb, Croatia; \\ ${ }^{3}$ Department of Internal Medicine, Sestre milosrdnice University Hospital Centre, Zagreb, Croatia; \\ ${ }^{4}$ University of Zagreb, School of Dental Medicine, Zagreb, Croatia; \\ ${ }^{5}$ Department of Radiology, Sestre milosrdnice University Hospital Centre, Zagreb, Croatia; \\ ${ }^{6}$ Department of Neurosurgery, Sestre milosrdnice University Hospital Centre, Zagreb, Croatia; \\ 'University of Applied Health Sciences, Zagreb, Croatia; \\ ${ }^{8}$ Josip Juraj Strossmayer University of Osijek, Faculty of Medicine, Osijek, Croatia; \\ ${ }^{9}$ University of Zagreb, School of Medicine, Zagreb, Croatia
}

\begin{abstract}
SUMMARY - Spontaneous resolution of nonfunctioning pituitary adenoma after hemorrhagic apoplexy is a rare clinical entity of unknown etiology and is defined as disappearance of a tumor without any specific treatment. Here we present a 54-year-old male patient who presented with acute onset of severe headache, vomiting, photophobia, and sonophobia. He was referred to brain computed tomography, which showed a 16x12x16 mm tumor mass located in the sellar region with signs of hemorrhage. Endocrinologic evaluation was consistent with under-function of pituitary gonadotropic cells. Magnetic resonance imaging (MRI) performed ten days later was consistent with hemorrhagic apoplexy of the pituitary adenoma. The patient's symptoms resolved after conservative treatment with dexamethasone, but he was scheduled for elective pituitary surgery. Preoperative MRI was performed one month after the first one and disclosed normal pituitary gland without any signs of adenoma. Our case is remarkable due to the fact that spontaneous remission of pituitary adenoma occurred within the first month, which is the shortest interval reported to date. Our case highlights the importance of conservative therapy as the first-line treatment for pituitary apoplexy in the absence of neurological impairment, since spontaneous remission may occur in a short time interval.
\end{abstract}

Key words: Pituitary neoplasms; Pituitary apoplexy; Adenoma; Empty sella syndrome; Neoplasm regression, spontaneous; Remission, spontaneous

\section{Introduction}

Pituitary gland, also known as hypophysis, is a gland located at the skull base in the area called sella turcica ${ }^{1}$. Pituitary adenomas are the most common tu-

Correspondence to: Luka Komić, medical student, School of Medicine, University of Split, Šoltanska 2, HR-21000 Split, Croatia E-mail: luka141196@gmail.com

Received January 29, 2021, accepted April 12, 2021 mors of the sellar region and they grow from adenohypophysis cells. They account for $15 \%$ of all intracranial tumors. Depending on the size, they are divided into microadenomas $(<10 \mathrm{~mm})$ and macroadenomas $(>10 \mathrm{~mm})$. With rapid improvement of new neuroradiological diagnostic procedures and ever greater power, precision and availability of magnetic resonance imaging (MRI) machines, it has become clear that their incidence is much higher than assumed. Their 
prevalence is estimated to $0.1 \%$ in the general population $^{2}$, while autopsy series have reported a prevalence of $25 \%{ }^{3}$. Pituitary adenomas are referred to as incidentalomas if they are an incidental finding in asymptomatic patients ${ }^{3}$. Pituitary apoplexy $(\mathrm{PA})$ is a rare clinical syndrome that occurs due to ischemic or hemorrhagic necrosis of the pituitary gland, and it is found as a complication in $2 \%-12 \%$ of pituitary tumors, especially nonfunctioning adenomas ${ }^{4}$. Most of these patients have PA as an initial manifestation of the underlying pituitary tumor ${ }^{5,6}$. It is more frequent in men during the $5^{\text {th }}$ and $6^{\text {th }}$ decades of life $\mathrm{e}^{7,8}$. Patients with symptomatic PA complain of sudden and intense headache, rapid and dramatic visual impairment, vomiting, and, in the most severe cases, impaired consciousness?. Headache is often retro-orbital or frontal, intense and lancinating, and insensitive to analgesics ${ }^{10}$.

Apoplexy is likely to induce spontaneous disappearance of those tumors. After hemorrhage and consequent necrosis, pituitary adenomas may sometimes be reabsorbed by the healthy tissue and vasculature in the surrounding area, which results in spontaneous adenoma resolution ${ }^{11}$.

To date, only 13 cases of nonfunctioning pituitary adenomas with spontaneous resolution have been reported in the world's literature ${ }^{12}$. The shortest time interval during which reduction in tumor volume occurred was 27 days $^{13}$, whereas the shortest period of complete spontaneous resolution reported so far was 45 days $^{14}$. In this case report, we describe complete spontaneous tumor resolution within 28 days.

\section{Case Report}

A 54-year-old man presented to the emergency neurological department with acute onset of severe headache in the frontal area with pulsative character, associated with vomiting, photophobia and sonophobia. The patient had been taking paracetamol in the last six hours, without any relief of symptoms. His medical history was unremarkable.

After general and neurological examination, which were unremarkable, the patient was referred to emergency brain computed tomography (CT) with con-

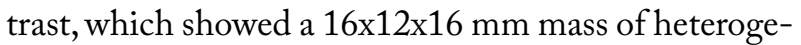
neous density and a central hyperdense area located in the sellar and suprasellar region, consistent with pituitary macroadenoma with signs of hemorrhage. An ac- cidental finding of a $12 \times 9 \mathrm{~mm}$ meningioma in the parasagittal left frontal lobe was also reported. Based on the clinical and radiological findings, the patient was diagnosed with hemorrhagic PA. He was admitted to the hospital and antiedematous therapy with 24 $\mathrm{mg}$ of dexamethasone was initiated. Laboratory evaluation showed normal complete blood count, biochemical parameters and tumor markers. Endocrinological evaluation disclosed normal function of pituitary somatotropic, lactotropic and thyrotropic cells. Morning cortisol was suppressed due to antiedematous therapy, whereas the remaining findings were consistent with central hypogonadism: luteinizing hormone 0.658 IU/L (normal, 1.7-8.6 IU/L), follicle-stimulating hormone 1.35 IU/L (normal, 1.5-12.4 IU/L), total testosterone $1.010 \mathrm{nmol} / \mathrm{L}$ (normal, 6.68-25.7 nmol/L), sex hormone binding globulin $90.09 \mathrm{nmol} / \mathrm{L}$ (normal, $14.5-48.4 \mathrm{nmol} / \mathrm{L}$ ), and free testosterone $0.009 \mathrm{nmol} / \mathrm{L}$ (normal, 0.204-0.637 nmol/L). The patient's symptoms resolved after conservative treatment with dexamethasone within two days.

Ten days of admission, magnetic resonance imaging (MRI) was performed to show a $16 \times 13 \times 18 \mathrm{~mm}$ mass with high signal intensity on T1-weighted images and heterogeneous post-contrast imbibition located in the sellar and suprasellar region. The mass obliterated the suprasellar cistern and spread to the optic chiasm without compressing it, caudally thinned and remodeled the bottom of the sella turcica and dorsally also the dorsum of the sella turcica, while the cavernous sinuses appeared free, consistent with pituitary macroadenoma with signs of hemorrhage (Fig. 1). Goldmann perimetry results were normal. The patient was discharged from the hospital with a recommendation to seek consultation at the national reference center for pituitary tumors for preoperative preparation and operative treatment.

At the national center, preoperative endocrinological and neuroradiological evaluations were performed. Low levels of total testosterone $4.1 \mathrm{nmol} / \mathrm{L}$ (normal, 6.68-25.7 nmol/L), suboptimal cortisol response during low-dose Synacthen test (cortisol I $286 \mathrm{nmol} / \mathrm{L}$, cortisol II $480 \mathrm{nmol} / \mathrm{L}$, cortisol III $337 \mathrm{nmol} / \mathrm{L}$ ) and low normal T4 $77 \mathrm{nmol} / \mathrm{L}$ (normal, 76-157 nmol/L) and thyroid-stimulating hormone $1.369 \mathrm{mIU} / \mathrm{L}$ (normal, 0.34-5.60 mIU/L) were found. Preoperative MRI, which was performed exactly 28 days after the first one, showed the pituitary of appropriate dimen- 


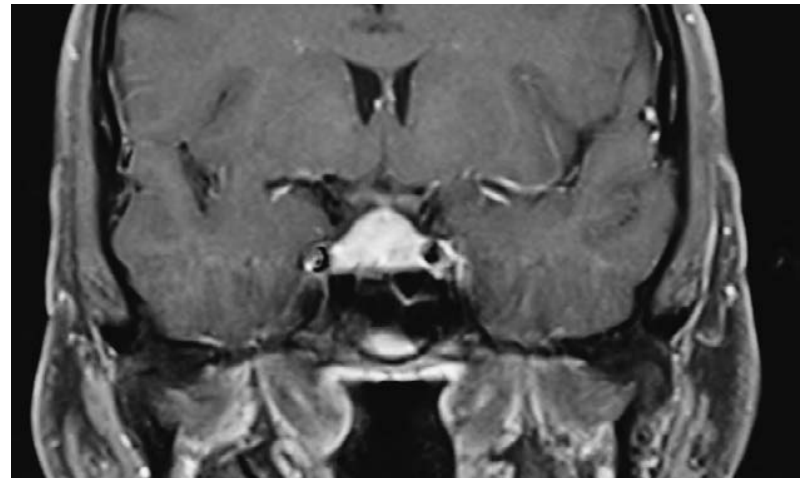

Fig. 1. Coronal T1-weighted magnetic resonance image demonstrating a $16 \times 13 \times 18 \mathrm{~mm}$ mass located in the sellar and suprasellar region.

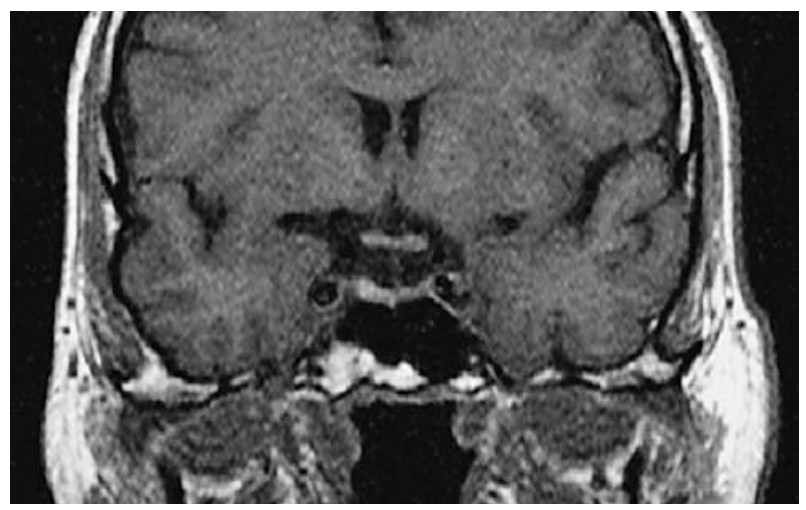

Fig. 2. Coronal T1-weighted preoperative magnetic resonance image performed after 28 days demonstrating pituitary gland of appropriate dimensions for age, without any signs of adenoma and with the remaining hemorrhagic area in the right half of the adenohypophysis.

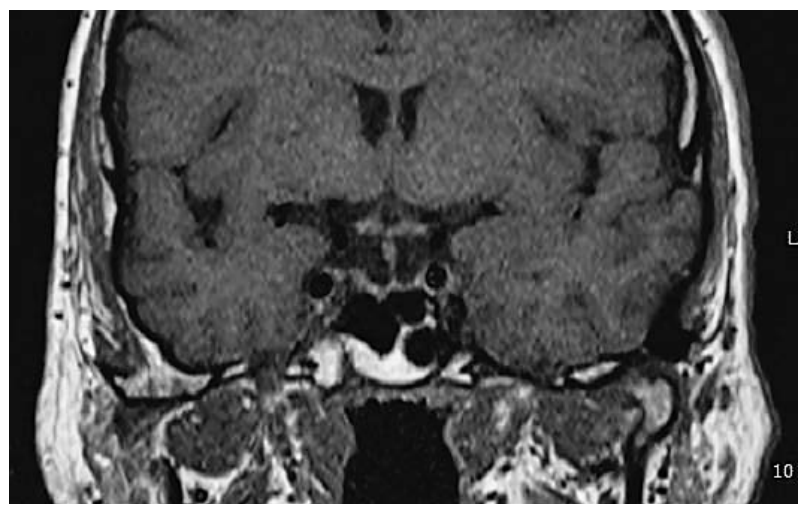

Fig. 3. Coronal T1-weighted magnetic resonance image obtained at 3-month follow-up demonstrating the partially empty sella without any signs of adenoma.

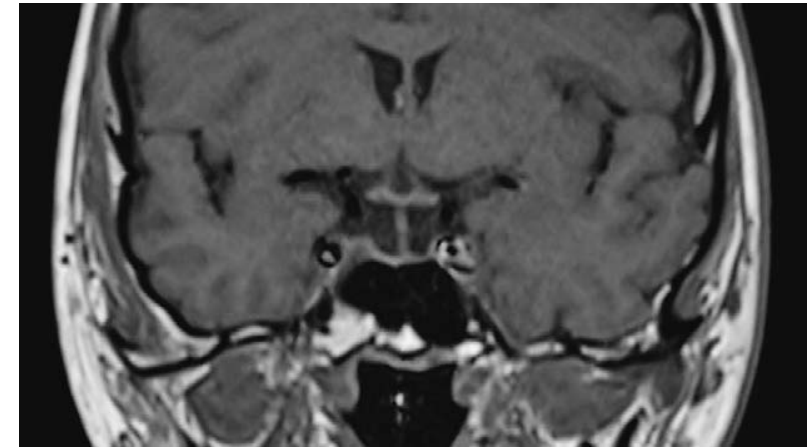

Fig. 4. Coronal T1-weighted magnetic resonance image obtained at 12-month follow-up demonstrating the partially empty sella without any signs of adenoma.

sions for age, without any signs of adenoma, discretely raised right half of the adenohypophysis with the visible dominant high intensity signal on T1-weighted

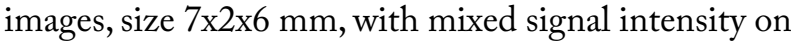
T2-weighted images. The pituitary gland showed relatively homogeneous imbibition on the post-contrast images. These findings could be explained with the remaining hemorrhagic area in the right half of the adenohypophysis without any signs of adenoma. Optic chiasm had normal appearance (Fig. 2). Hence, MRI showed no signs of pituitary tumor and it was consistent with spontaneous resolution of nonfunctioning pituitary adenoma. The patient was discharged from the hospital without surgical intervention and with recommendation to take replacement therapy (hydrocortisone $5 \mathrm{mg}$ in the morning and $2.5 \mathrm{mg}$ at $5.00 \mathrm{PM}$ per os, levothyroxine sodium $25 \mathrm{mcg}$ in the morning per os and testosterone $50 \mathrm{mg}$ topically). Follow-up appointment was scheduled in 3 months.

At the 3-month follow-up, the patient stated that he had not taken the recommended replacement therapy. Endocrinological re-evaluation was consistent with normal function of all pituitary cells. Repeated MRI showed a distinctly thinned pituitary gland leaning broadly against the bottom of the sella, consistent with the partially empty sella, without any signs of adenoma. The right half of the adenohypophysis had a slightly inhomogeneous structure and the pituitary stalk was minimally slanted to the left with normal thickness and post-contrast imbibition. Optic chiasm and cavernous sinuses had normal appearance (Fig. 3). The patient was in good general condition and discharged from the hospital without any replacement 
therapy, and scheduled for re-evaluation in one-year period.

At the 12-month follow-up, endocrinological reevaluation was again consistent with normal function of all pituitary cells. MRI also remained unchanged throughout the follow-up period and was consistent with the partially empty sella, without any signs of adenoma (Fig. 4).

\section{Discussion}

To our knowledge, we are the first to describe a case of complete spontaneous resolution of a nonfunctioning pituitary adenoma within the first month (28 days), while the shortest period described so far in the literature was 45 days $^{14}$. Spontaneous tumor resolution in this case was most likely because of infarction, hemorrhage and necrosis. Spontaneous resolution of nonfunctioning pituitary adenoma is an uncommon phenomenon. To the best of our knowledge, 13 cases of spontaneous resolution of nonfunctioning adenomas have been reported ${ }^{12}$.

In addition to complete tumor resolution in most cases, Eichberg et al. found that $23 \%$ of cases resulted in the development of empty sella and hypopituitarism, $8 \%$ in decreased tumor size but still radiographically visible, and $8 \%$ in tumor regrowth after resolution $^{12}$. The pathophysiology underlying spontaneous resolution after apoplexy is not fully understood so $\mathrm{far}^{15}$. After hemorrhage and consequent necrosis, pituitary adenomas sometimes may be reabsorbed by the healthy tissue and vasculature in the surrounding area, which results in spontaneous adenoma resolution ${ }^{11}$. The mechanism of PA also remains unclear. In comparison to the normal pituitary gland, blood supply to pituitary adenomas is diminished and there is also evidence that pituitary adenomas have impaired angiogenesis and reduced vessel density ${ }^{16}$. Consequently, one of the proposed mechanisms of PA is that the rapid tumor growth may outstrip arterial blood supply and lead to ischemia ${ }^{17}$. Alternatively, the mass effect of the growing tumor may compress the pituitary vessels, thus compromising blood flow to a tumor with intrinsically poor vascularity and leading to ischemia and hemorrhagic infarction ${ }^{18}$. Although it can occur without any risk factors, many patients with PA have some precipitating factors such as systemic hypertension, major surgery, coagulopathies, anticoagulation, throm- bolytic and antiplatelet therapy, estrogen therapy, pregnancy, postpartum state, radiation therapy, or head trauma ${ }^{19-21}$.

Although there is a universal consensus that, once PA is diagnosed, high-dose corticosteroids should be administered immediately along with supportive measures to ensure hemodynamic stability, further management of PA is still a matter of debate. In patients with acute and severe forms of PA, which include significant neuro-ophthalmic impairment or altered level of consciousness, transsphenoidal surgical decompression is considered the gold standard technique, whereas in patients without visual acuity or field defects and with normal consciousness some adopt conservative approach ${ }^{18}$. One of the first to suggest conservative approach were Pelkonen et al. in 1978, whereas Maccagnan et al. report that conservative management was possible in $60 \%$ of patients with a similar post-treatment prevalence of pituitary hormone deficiency and incidence of tumor recurrence in patients who underwent surgical or conservative treatment ${ }^{22,23}$. Kirigin Biloš et al. postulate that conservative management of PA may be a proper alternative to surgery, although it is challenging to assess which patients can be safely monitored versus those at risk of negative outcomes because the risk factors for tumor progression or recurrent apoplexy remain unknown ${ }^{24}$.

In our case, the patient presented with acute onset of severe headache associated with vomiting, photophobia and sonophobia. The patient's symptoms resolved after conservative treatment with dexamethasone but he was scheduled for elective pituitary surgery, which was not performed because preoperative MRI disclosed normal pituitary gland without any signs of adenoma. Our case emphasizes the importance of analyzing all preoperative cranial imaging prior to surgery and highlights the importance of conservative therapy as the first-line treatment for PA in the absence of neurological impairment, since spontaneous remission may occur in short time interval. In addition, we strongly recommend re-evaluation of pituitary function and MRI by the multidisciplinary pituitary teams to surveil for possible tumor recurrence.

\section{References}

1. Javorsky BR, Aron DC, Findling JW, Tyrrel JB. Hypothalamus and pituitary gland. In: Gardner DG, Shoback D, editors. 
Greenspan's Basic and Clinical Endocrinology, 9 ${ }^{\text {th }}$ Edition. New York: The McGraw-Hill Companies Inc.; 2011:65.

2. Daly AF, Rixhon M, Adam C, Dempegioti A, Tichomirowa MA, Beckers A. High prevalence of pituitary adenomas: a cross-sectional study in the province of Liege, Belgium. J Clin Endocrinol Metab. 2006;91:4769-75. DOI: 10.1210/ jc.2006-1668

3. Gnjidić Ž, Stipić D. Epidemiologija tumora hipofize (Epidemiology of pituitary tumors). Med Flum. 2011;47(2):185-90. (in Croatian)

4. Albani A, Ferraù F, Angileri FF, Esposito F, Granata F, Ferreri $\mathrm{F}$, et al. Multidisciplinary management of pituitary apoplexy. Int J Endocrinol. 2016;2016:1. DOI: 10.1155/2016/7951536

5. Sibal L, Ball SG, Connolly V, et al. Pituitary apoplexy: a review of clinical presentation, management and outcome in 45 cases. Pituitary. 2004;7(3):157-63. DOI: 10.1007/s11102005-1050-3

6. Semple PL, Jane JA Jr, Laws ER Jr. Clinical relevance of precipitating factors in pituitary apoplexy. Neurosurgery. 2007;61(5): 956-61. DOI: 10.1227/01.neu.0000303191.57178.2a

7. Chhiber SS, Bhat AR, Khan SH, et al. Apoplexy in sellar metastasis: a case report and review of literature. Turk Neurosurg. 2011;21(2):230-4. DOI: 10.5137/1019-5149.JTN.2716-09.1

8. Randeva HS, Schoebel J, Byrne J, Esiri M, Adams CBT, Wass JAH. Classical pituitary apoplexy: clinical features, management and outcome. Clin Endocrinol. 1999;51(2):181-8. DOI: 10.1046/j.1365-2265.1999.00754.x

9. Ayuk J, McGregor EJ, Mitchell RD, Gittoes NJL. Acute management of pituitary apoplexy - surgery or conservative management? Clin Endocrinol. 2004;61(6):747-52. DOI: 10.1111/j.1365-2265.2004.02162.x

10. Johnston PC, Hamrahian AH, Weil RJ, Kennedy L. Pituitary tumor apoplexy. J Clin Neurosci. 2015;22(6):939-44. DOI: 10.1016/j.jocn.2014.11.023

11. Wu Z, Su Z, Wu J. Spontaneous remission of pituitary macroadenomas in women: report of two cases. Chin Med J. 2007;120:2062-4.

12. Eichberg DG, Di L, Shah AH, Kaye WA, Komotar RJ. Spontaneous preoperative pituitary adenoma resolution following apoplexy: a case presentation and literature review. Br J Neurosurg.2018 Nov;19:1-6.DOI:10.1080/02688697.2018.1529737
13. Yoshino A, Katayama Y, Watanabe T, Hirota H. Vanishing pituitary mass revealed by timely magnetic resonance imaging: examples of spontaneous resolution of nonfunctioning pituitary adenoma. Acta Neurochir (Wien). 2005;147:253-7. DOI: 10.1007/s00701-004-0443-9

14. Kachhara R, Nair S, Gupta A. Spontaneous resolution of a non-functioning pituitary adenoma following an apoplexy. Neurol India. 2000;48:294-6.

15. Liu S, Wang X, Liu Y-H, Mao Q. Spontaneous disappearance of the pituitary macroadenoma after apoplexy: a case report and review of the literature. Neurol India. 2012;60:530-2. DOI: $10.4103 / 0028-3886.103211$

16. Oldfield EH, Merrill MJ. Apoplexy of pituitary adenomas: the perfect storm. J Neurosurg. 2015;122:1444-9. DOI: 10.3171 /2014.10.JNS141720

17. Epstein S, Pimstone BL, De Villiers JC, Jackson WP. Pituitary apoplexy in five patients with pituitary tumours. Br Med J. 1971;2:267-70. DOI: 10.1136/bmj.2.5756.267

18. Briet C, Salenave S, Bonneville J-F, Laws ER, Chanson P. Pituitary apoplexy. Endocr Rev. 2015;36:622-45. DOI: 10.1210/ er.2015-1042

19. Mou C, Han T, Zhao H, Wang S, Qu Y. Clinical features and immunohistochemical changes of pituitary apoplexy. J Clin Neurosci. 2009;16:64-8. DOI: 10.1016/j.jocn.2008.02.012

20. Biousse V, Newman NJ, Oyesiku NM. Precipitating factors in pituitary apoplexy. J Neurol Neurosurg Psychiatry. 2001;71: 542-5. DOI: 10.1136/jnnp.71.4.542

21. Murad-Kejbou S, Eggenberger E. Pituitary apoplexy: evolution, management and prognosis. Curr Opin Ophthalmol. 2009;20:456-61. DOI: 10.1097/ICU.0b013e3283319061

22. Pelkonen R, Kuusisto A, Salmi J, Eistola P, Raitta C, Karonen SL, Aro A. Pituitary function after pituitary apoplexy. Am J Med. 1978;65:773-8. DOI: 10.1016/0002-9343(78)90795-7

23. Maccagnan P, Macedo CL, Kayath MJ, Nogueira RG, Abucham J. Conservative management of pituitary apoplexy: a prospective study. J Clin Endocrinol Metab. 1995;80:2190-7. DOI: $10.1210 /$ jcem.80.7.7608278

24. Kirigin Biloš LS, Kruljac I, Radošević JM, Ćaćić M, Škoro I, Črina V, et al. Empty sella in the making. World Neurosurg. 2019;128:366-70. DOI: 10.1016/j.wneu.2019.05.119 
Sažetak

\title{
SPONTANI NESTANAK NEFUNKCIONALNOG ADENOMA HIPOFIZE U MJESEC DANA: PRIKAZ SLUČAJA
}

\author{
L. Komić, I. Kruljac, G. Mirošević, P. Gaćina, H. I. Pećina, V. Čerina, D. Gajski, K. Blaslov, K. Rotim i M. Vrkljan
}

Spontana regresija nefunkcionalnog adenoma hipofize nakon hemoragijske apopleksije je iznimno rijedak klinički entitet nepoznate etiologije, a definiran je kao nestanak tumora bez primijenjenog liječenja. Naš 54-godišnji bolesnik prezentirao se izrazito jakom, naglo nastalom glavoboljom, povraćanjem, fotofobijom i sonofobijom. Bolesnik je upućen na hitnu kompjutoriziranu tomografiju mozga koja je pokazala selarnu tumorsku tvorbu 16x12x16 mm sa zonom krvarenja. Endokrinološki nalazi upućivali su na disfunkciju gonadotropnih stanica hipofize. Nakon deset dana učinjena je magnetska rezonanca (MR) kojom je potvrđena hemoragijska apopleksija adenoma hipofize. Simptomi su se povukli nakon primijenjene konzervativne terapije deksametazonom, ali je bolesnik zakazan za kiruršku resekciju adenoma. Prijeoperacijski MR učinjen mjesec dana nakon prvoga pokazao je normalnu hipofizu bez znakova adenoma. Posebnost našega slučaja je vrijeme manje od mjesec dana u kojem se dogodila spontana remisija, što je najkraće dosad opisano vrijeme u svjetskoj literaturi. Naš slučaj naglašava važnost konzervativne terapije kao prve terapijske linije kod apopleksije adenoma hipofize u bolesnika bez neuroloških deficita i to upravo zbog činjenice što je spontana remisija moguća u kratkom vremenskom intervalu nakon pojave samih simptoma.

Ključne riječi: Tumori hipofize; Apopleksija hipofize; Adenom; Sindrom prazne sele; Regresija tumora, spontana; Remisija, spontana 